\title{
Kontribusi Antara Daya Ledak Tungkai Kaki Terhadap Hasil Belajar Praktek Tolak Peluru Mahasiswa Jurusan Pendidikan Kepelatihan Olahraga Fakultas Ilmu Keolahragaan Universitas Negeri Padang
}

\author{
Yusra Fauza $^{1}$, Hilmainur Syampurma ${ }^{2}$, Endang Sepdanius ${ }^{3}$ \\ ${ }^{123}$ Fakultas Ilmu Keolahragaan, Universitas Negeri Padang, Indonesia. \\ E-mail: yusra@gmail.com ${ }^{1}$, hilmainursyampurma@,fik.unp.ac.id ${ }^{2}$, endangsepdanius@,fik.unp.ac.id ${ }^{3}$
}

\begin{abstract}
Abstrak
Penelitian ini bertujuan untuk mengetahui tentang kontribusi antara "daya ledak tungkai kaki sebagai variabel bebas dan hasil belajar praktek tolak peluru sebagai varibel terikat, penelitian ini dilaksanakan di Fakultas Ilmu Keolahragaan UNP. Teknik pengambilan sampel dengan teknik Random Sampling dan didapat sampel sebanyak 60 orang mahasiswa.

Pengambilan data daya ledak tungkai kaki dengan cara melakukan vertical jump. Untuk hasil belajar praktek tolak peluru dengan melakukan perlakuan/tolak peluru. Analisis data dan pengujian hipotesis penelitian menggunakan teknik analisis korelasi product moment dengan taraf signifikan $\alpha=$ 0,05 ,

Dari analisis data dapat diperoleh hasil : 1) Terdapat kontribusi yang berarti antara daya ledak tungkai kaki terhadap hasil belajar praktek tolak peluru dengan perolehan $r_{\text {hitung }} 0,550>r_{\text {tabel }} 0,250.2$ ) terdapat kontribusi yang berarti antara daya ledak tungkai kaki terhadap hasil belajar praktek tolak peluru dalam hal ini tingkat hubungan daya ledak tungkai kaki dengan hasil belajar praktek tolak peluru sebesar 30,2\%, maksudnya semakin bagus daya ledak tungkai kaki seseorang maka semakin baik pula hasil belajar praktek tolak peluru.
\end{abstract}

Kata Kunci: Daya Ledak Tungkai Kaki, Hasil Belajar Praktek Tolak Peluru, Atletik, Tolak Peluru, Hasil Belajar

\begin{abstract}
The study aims to find out about the contributions between the "explosive power of the legs as a variable free and the outcome of learning the practice of bullet reject as a bound the, this research was conducted in the Faculty of Sports Sciences UNP. Sampling techniques with Random Sampling techniques and sampled 60 students.

Data retrieval of leg-blast power by vertical jump. For learning Results The bullet-reject practice by conducting a bullet treatment. Analysis of data and research hypothesis testing using the correlation analysis technique of product moment with a significant level of $\alpha=0.05$,

From data analysis can be obtained results: 1) There is a meaningful contribution between the explosive power of the leg to the outcome of the practice of the bullet-learn with the acquisition of Rcount $0.550>$ Rtabel 0.250. 2) There is a meaningful contribution between the explosive power of the legs to the outcome of the practice of the bullet reject in this case the level of explosive power of the legs with a result of the practice of bullet-learning of 30.2\%, meaning the better the explosive power of the leg of one's legs then the better learning results of the bullet reject.
\end{abstract}

Keywords: Explosive power legs, Learning outcomes practice reject, Athletics, Bullet reject, Learning outcomes

\section{PENDAHULUAN (10\%)}

Seiring dengan arah kebijakan pembangunan Nasional Pasca Reformasi yang memberikan dominasi pada kepentingan publik diantaranya tantangan terhadap pembangunan Olahraga tidaklah 
semakin ringan. "Olahraga dan pembangunan Mutohir (2004: 02 ) ada tiga tantangan yang akan dihadapi bangsa Indonesia ke depan dalam meningkatkan pembangunan Olahraga, yaitu :

1. Tingginya tuntutan publik terhadap prestasi olahraga.

2. Menjadikan olahraga sebagai instrument pembangunan.

3. Desentralisasi pembangunan olahraga. ketiga tantangan tersebut, baik secara sendiri-sendiri maupun secara bersama - sama perlu dicermati dan diantisipasi secara sungguh- sungguh.

Pendapat tersebut di atas dalam pendidikan jasmani dan olahraga merupakan bagian yang integral dari pendidikan yang dapat memberikan sumbangan berharga bagi pertumbuhan dan perkembangan manusia seutuhnya. Untuk mewujudkan semua itu perlu dibentuk lembaga-lembaga yang berperan dalam rangka meningkatkan sumber daya manusia khususnya di bidang olahraga, salah satu lembaga tersebut adalah Perguruan Tinggi.

Dari berbagai perguruan tinggi yang ada di Sumatera Barat, Universitas Negeri Padang merupakan satu satunya perguruan tinggi yang mempunyai Fakultas Ilmu Keolahragaan (FIK). Fakultas Ilmu Keolahragaan merupakan lembaga Pendidikan tinggi yang berdasarkan pada iman dan taqwa, mengembangkan diri secara kreatif, inovatif dan produktif untuk membentuk kemampuan adaptasi terhadap perubahan dan perkembangan masyarakat.

Ilmu pengetahuan dan teknologi, sebagai upaya memberikan pelayanan secara ilmiah dan propesional kepada masyarakat dan sebagai agent of change dalam bidang olahraga. FIK UNP memiliki misi sebagai lembaga pendidikan tinggi yang merupakan wadah pusat pengkajian ilmu keolahragaan yang menggali dan mengembangkan serta memelihara ilmu pengetahuan dan teknologi keolahragaan dan memperluas hasil-hasilnya agar bisa dimanfaatkan bagi kemaslahatan masyarakat. (Pedoman Akademik UNP 2003 : 82).

Pada Fakultas Ilmu Keolahragaan Universitas Negeri Padang terdapat tiga jurusan yaitu : Pendidikan Kepelatihan Olahraga, Pendidikan Olahraga dan Pendidikan Kesehatan dan Rekreasi. Dari ketiga jurusan yang tersebut di atas salah satu diantaranya Jurusan Pendidikan Kepelatihan Olahraga, dengan mempunyai dua tujuan yaitu menghasilkan tenaga profesional dalam bidang pendidikan jasmani, serta kepelatihan olahraga. Di samping tujuan yang lain. jurusan pendidikan kepelatihan olahraga adalah sebagai lembaga yang memiliki lulusan yang mempunyai kompetensi antara lain memiliki kemampuan dan dan sikap positif serta dapat mengaplikasikan IPTEKS dalam bidang kepelatihan olahraga dan dalam bidang pendidikan jasmani. (Pedoman Akademik UNP 2003 : 116)

Pada Jurusan Pendidikan Kepelatihan Olahraga memiliki kurikulum yang diantaranya menjadikan cabang-cabang olahraga menjadi mata kuliah, ada yang dimasukkan ke dalam kategori mata kuliah wajib, dan ada dimasukkan ke dalam kategori mata kuliah pilihan, dan semua itu harus diselesaikan oleh semua mahasiswa jurusan pendidikan kepelatihan olahraga. Salah satu di antara cabang olahraga yang dijadikan mata kuliah wajib pada kurikulum Jurusan Pendidikan Kepelatihan Olahraga adalah Atletik. Pada Perkuliahan terdapat tiga tingkatan yaitu : atletik dasar, atletik pendalaman, dan atletik spesialisasi. Atletik adalah olahraga yang membutuhkan kondisi fisik seperti daya tahan, kekuatan, kecepatan, koordinasi.

Di dalam atletik terdapat beberapa nomor - nomor yang menjadi materi dalam perkuliahan yang harus dipelajari oleh mahasiswa. salah satunya adalah nomor tolak peluru. Pada nomor tolak peluru membutuhkan daya ledak yang merupakan dasar dari pelaksanaan gerakan kondisi fisik, agar dapat melakukan tolakan yang optimal. Berdasarkan pengamatan yang di lakukan peneliti di lapangan yang diarahkan oleh Dosen pembibimbing yaitu Bapak Drs. M.Ridwan bahwasanya, kemampuan tolak peluru mahasiswa Fakultas Ilmu Keolahragaan masih rendah, dari harapan yang di inginkan Dosen.

Sehubungan apa yang diterangkan di atas dapat dilihat bahwa keberhasilan seorang mahasiswa mencapai hasil yang baik dalam belajar tolak peluru, ditentukan banyak faktor, salah satunya adalah daya ledak tungkai kaki. oleh karena itu penelitian ini penting untuk dilakukan sehingga memperoleh informasi yang menentukan apakah terdapat kontribusi antara daya ledak tungkai kaki dengan 
kemampuan tolak peluru. Tolak peluru adalah salah satu nomor dalam cabang olahraga atletik dalam pelaksanaan tolak terdapat beberapa macam teknik yaitu teknik ortodoks, teknik o brian, dan rotasi Teknik dasar Tolak Peluru menurut PB PASI (1979: 16)

a. Cara memegang alat

Peluru harus berada pada akar jari-jari tangan, jari pertama, kedua dan ketiga (telunjuk, jari tengah dan kelingking) merupakan titik-titik kontak yang utama dan membantu menolak. Jari-jari ini tidak boleh berjauhan jari kelingking berguna untuk menjaga kestabilan peluru. peluru harus dijaga agar tetap berada di bawah rahang.
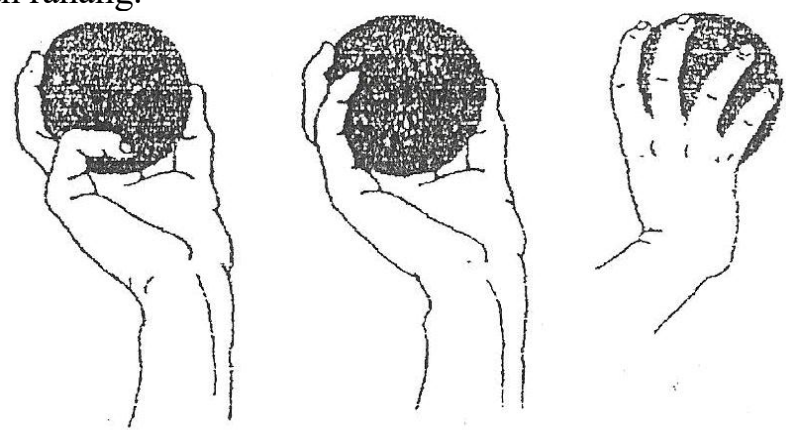

b. Awalan

\section{Gambar 1. Cara Memegang Peluru}

Dagu, lutut dan ujung jari kaki kanan harus berada pada satu garis lurus vertikal. Punggung jangan terlalu membungkuk. Jarak antara dua kaki disesuaikan dengan tinggi atlit.

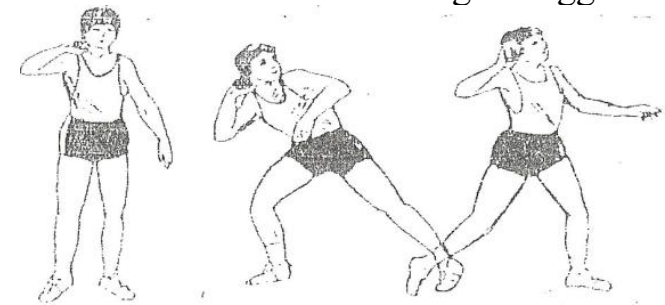

\section{Gambar 5. Sikap Badan Menyamping Pada Waktu Akan Melakukan Awalan}

\section{c. Sikap tolakan}

Berdiri tegak menyamping ke arah tolakan, kaki membuka lebar, kaki kiri lurus ke depan, kaki kanan dengan lutut dibengkokkan ke depan sedikit agak serong ke samping kanan. Berat badan pada kaki kanan. Badan agak condong ke samping kanan. Tangan kanan memegang peluru pada bahu, tangan kanan memegang peluru pada bahu, tangan kiri dan siku dibengkokkan berada di depan agak serong ke atas. Tangan kiri berfungsi untuk membantu dan menjaga keseimbangan. Pandangan ke arah tolakan. Gerakan ini akan terlihat pada gambar sebagai berikut :

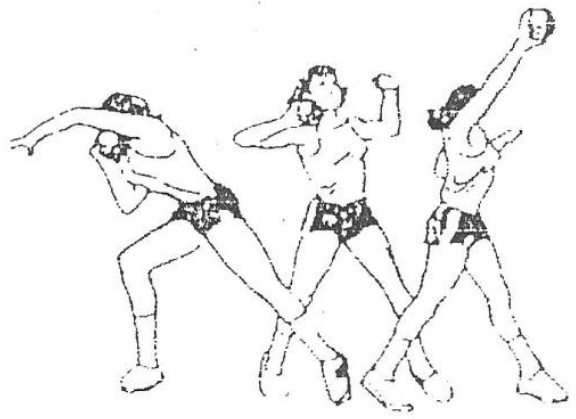

Gambar 6. Cara Menolak dengan Sikap Menyamping 
d. Cara menolakkan peluru

Bersamaan dengan memutar badan ke arah tolakan, siku ditarik serong ke arah atas belakang, pinggul dan pinggang didorong ke depan agak ke atas hingga dada terbuka menghadap ke depan serong ke atas arah tolakan. Pada saat seluruh badan menghadap ke arah tolakan. Pada saat seluruh badan menghadap ke arah tolakan bersamaan dengan bantuan menolakkan kaki kanan dan melonjakkan kaki kanan melonjakan seluruh badan ke atas serong ke depan.

e. Sikap badan setelah menolak.

Pada saat setelah menolak peluru untuk menjaga keseimbangan badan agar tidak keluar dari sirkel dilakukan gerakan lanjutan (Follow Through) atau sikap akhir. Yaitu suatu gerakan setelah peluru dilepaskan dari tangan.

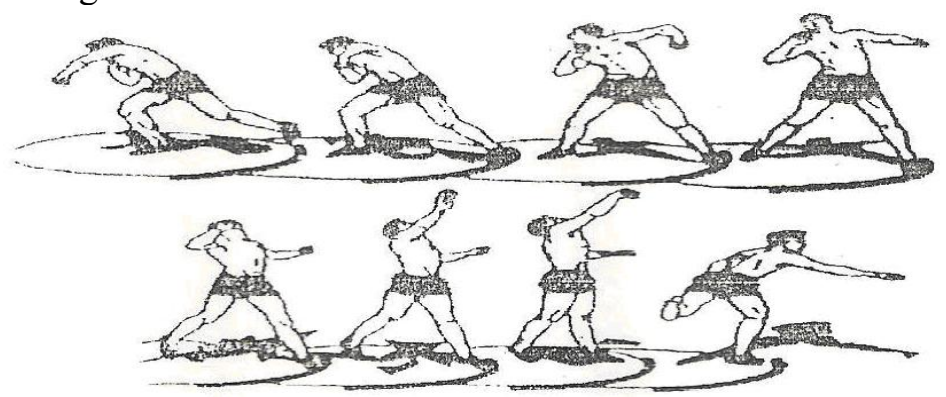

Gambar 7. Tolak Peluru dengan Awalan Menyamping

Seperti yang telah diuraikan pada kajian teoritis, Hakekat daya ledak Tungkai kaki dari pengertian di atas dapat simpulkan bahwa daya ledak tungkai kaki, adalah suatu kemampuan otot tungkai kaki untuk mengatasi beban/tahanan dengan kuat dan cepat dengan kontraksi tinggi, Selanjutnya hakekat kemampuan tolak peluru adalah kemampuan seorang untuk menolakkan peluru sejauh mungkin dengan memaksimalkan jarak.

\section{METODE}

Jenis penelitian ini adalah penelitian korelasional yang melihat Kontribusi antara variable bebas dengan variable terikat. Adapun variabel bebas adalah Daya Ledak tungkai kaki dan variabel terikat adalah kemampuan tolak peluru mahasiswa jurusan kepelatihan FIK UNP. Sesuai dengan jenis penelitian ini maka penelitian korelasi (Correlation research) menurut UNP (1999 : 11) yaitu : penelitian korelasi untuk melihat ada tidaknya, seberapa jauh, ditemukan korelasi antara dua variabel atau lebih secara kuantitatif.

Tempat penelitian dilakukan di Fakultas Ilmu Keolahragaan (FIK) UNP setelah proposal ini disetujui oleh tim penguji yang ditetapkan Jurusan Pendidikan Kepelatihan FIK UNP. Populasi penelitian ini adalah mahasiswa Jurusan Pendidikan Kepelatihan FIK UNP yang mengambil Mata Kuliah Atletik dasar. Dari informasi yang diperoleh pada Buku Panduan Jadwal Kuliah mata kuliah atletik terdiri dari 6 seksi, yang di ikuti dari 285 orang mahasiswa. Dengan rincian 264 orang Putra dan 21 orang putri. Untuk lebih jelas dapat dilihat pada tabel di bawah ini.

Tabel 1. Penyebaran Populasi

\begin{tabular}{llccc}
\hline No & Kode Seksi & Jumlah Putra & Jumlah Putri & Jumlah \\
1 & 5374 & 39 & 1 & 40 \\
2 & 5216 & 54 & 8 & 62 \\
3 & 1045 & 44 & 5 & 49 \\
4 & 0704 & 43 & 3 & 46 \\
5 & 5143 & 45 & 4 & 49 \\
6 & 1001 & 39 & - & 39 \\
& Jumlah & 264 & 21 & 285 \\
\hline
\end{tabular}


Sampel penelitian ini ditarik dengan Teknik Random Sample, secara acak dengan setiap subjek yang terdaftar sebagai populasi, dengan mengambil $23 \%$ dari jumlah populasi setiap seksi mata kuliah. Arikunto (2006 : 134) menyatakan "apabila subjek kurang dari 100 lebih baik diambil semua, sehingga penelitian merupakan penelitian populasi, jika jumlah subjek besar dapat diambil 10 - 15\% atau $20-25 \%$ tergantung dari kemampuan peneliti dilihat dari waktu, tenaga, dan dana, Sempit luasnya wilayah pengamatan dari setiap subjek karena ini hal ini menyangkut banyak sedikitnya data, besar kecilnya resiko yang ditanggung oleh peneliti, untuk penelitian yang resikonya besar, tentu saja jika sampel besar, hasilnya akan lebih baik"populasi tersebut di beri nomor dari 1 sampai dengan banyak populasi setiap seksi mata kuliah,.

Berhubung jumlah putra dan putri tidak berimbang karena jumlah putra lebih besar dari putri maka yang diambil sebagai sampel hanya putra saja. Untuk lebih jelas dapat dilihat pada tabel di bawah ini.

Tabel 2. Sampel

\begin{tabular}{ccccc}
\hline No & Kode Seksi & Jumlah Putra & Persentase 23\% & Jumlah \\
\hline 1 & 5374 & 39 & 8,97 & 9 \\
2 & 5216 & 54 & 12,42 & 12 \\
3 & 1045 & 44 & 10,12 & 10 \\
4 & 0704 & 43 & 9,89 & 10 \\
5 & 5143 & 45 & 10,35 & 10 \\
6 & 1001 & 39 & 8,97 & 9 \\
& Jumlah & 264 & 60,7 & 60 \\
\hline
\end{tabular}

Teknik pengumpulan data untuk kemampuan daya ledak tungkai kaki adalah dengan melakukan tes dengan Vertical Jump dan variabel hasil belajar meminta sampel melakukan Tolak Peluru kemudian mengambil jarak terjauh kemampuan tolak peluru dalam satuan meter.

\section{Instrument Penelitian}

Tujuan dari adanya pelaksnaan tes adalah agar testi tidak salah dalam melakukan tes yang sesungguhnya. Sehingga dalam pelaksanaanya benar - benar di pahami. Adapn prosedus pelaksananya adalah sebagai berikut :

\section{Tes Vertical Jump}
Alat yang digunakan
a. Papan ukuran
b. Kapur Halus
c. Formulir Pencatat data dan alat tulis

\section{Pelaksanaan Tes}

a. Testi berdiri menghadap dinding dengan salah satu lengan di luruskan lengan ke atas, lalu di catat tinggi jangkauan atau raihan pertama.

b. Testi berdiri dengan bagian samping tubuhnya menghadap dinding, lalu dia mengambil sikap jongkok sehingga lututnya membentuk sudut berkisar $110^{\circ}-120^{\circ}$.

c. Testi berusaha melompat ke atas (vertikal) setinggi mungkin, sambil mengayunkan kedua lenganya ke atas.

d. Pada saat titik tertinggi dari lompatan itu, ia segera menyentuhkan ujung jari dari salah satu tangannya pada papanyang mengisi dan meraih tempat ukuran kemudian mendarat dengan kedua kaki.

\section{Penilaian}

a. Selisih yang terbesar antara tinggi jangkauan sesudah melompat dengan tinggi jangkauan sebelum melompat.

b. Tinggi jangkauan diukur dalam satuan $\mathrm{cm}$.

c. setiap testi diberikan tiga kali kesempatn tes. 


\section{Tes kemampuan tolak peluru}

Alat yang digunakan

a. Peluru $6 \mathrm{~kg}$ untuk putra

b. Meteran 30

c. Cirkel tolak

\section{Pelaksanaan tes}

a. testi diminta menolakan peluru dengan awalan

b. testi diberikan kesempatan masing - masing tiga kali

\section{Penilaian}

Penilaian dilakukan dengan cara memberikan kesempatan kepada seluruh sampel, masing masing sampel diberikan sekaligus tiga kali tolakan, tolakan yang terbaik dari ketiga tolakan di ambil sebagai dasar penelitian.

Selanjutnya Berdasarkan pada hipotesis yang diajukan, analisis data yang dilakukan dengan menggunakan Statistik analisis korelasional product moment. Sebelum data dianalisis terlebih dahulu dilakukan uji normalisasi dengan uji Lilliefors dan uji linearitas persamaan regresi pada taraf signifikan 0,05. Analisis korelasi digunakan untuk membuktikan penelitian yang diajukan, adapun rumus korelasi tersebut menggunakan rumus korelasi Product Moment oleh Pearson dalam Sudjana (1992:382).

Uji signifikan korelasi, untuk dapat mengetahui apakah yang telah dihitung melalui koefisien itu signifikan atau tidak, maka perlu dilakukan langkah mencari uji signifikansi korelasi Menghitung besarnya kontribusi melalui indeks deskriminasi yaitu : $r^{2} x 100 \%$ data ini diolah dan dianalisis dan diolah dengan program Excel dan SPSS (Statistical Parcel Social Sciences) versi 12.

\section{HASIL DAN PEMBAHASAN}

\section{Hasil Penelitian}

Hasil pengumpulan data tentang daya ledak tungkai kaki dan kemampuan tolak peluru. Untuk lebih jelasnya masing-masing data dideskriptifkan sebagai berikut :

\section{Daya ledak tungkai kaki}

Dari hasil pengolahan data tentang daya ledak tungkai kaki dengan menggunakan Vertical Jump yang dilakukan terhadap sampel sebanyak 60 orang, didapat skor tertinggi 89,00 cm terendah 21,00 $\mathrm{cm}$ rata-rata (mean) $54,22 \mathrm{~cm}$, median $55,50 \mathrm{~cm}$, simpangan baku (standar deviasi) $=12,62$ modus $51,00 \mathrm{~cm}$. Untuk lebih jelasnya dapat dilihat pada tabel, berikut :

\section{Tabel 3 : Distribusi Frekuensi daya ledak tungkai kaki (X).}

\begin{tabular}{|c|c|c|c|}
\hline No. & Interval Kelas (cm) & Frekuensi Absolute (fa) & Relatif (fr) \\
\hline & $21-32$ & 4 & 7 \\
\hline & $33-44$ & 6 & 10 \\
\hline & $45-56$ & 23 & 38,8 \\
\hline & $57-68$ & 20 & 33,8 \\
\hline & $69-80$ & 5 & 8,8 \\
\hline & $81-92$ & 1 & 1,6 \\
\hline & Jumlah & 60 & 100,00 \\
\hline \multicolumn{4}{|c|}{$\begin{array}{c}\text { Mean }=54,22 \\
\text { Median }=55,50 \\
\text { Modus }=51,00 \\
\text { Standar deviasi }=12,62\end{array}$} \\
\hline
\end{tabular}


Berdasarkan pada tabel 4, distribusi frekuensi dari 60 orang sampel, 4 orang (7\%) memiliki daya ledak tungkai kaki $21-32,6$ orang $(10 \%)$ memiliki daya ledak tungkai kaki 33 - 44, 23 orang $(38,8 \%)$ memiliki daya ledak tungkai kaki $45-56,20$ orang $(33,8 \%)$ memiliki daya ledak tungkai kaki 57 - 68, 5 orang $(18,18 \%)$ memiliki daya ledak tungkai kaki $15,20-15,70$ dan 4 orang $(8,8 \%)$ memiliki daya ledak tungkai kaki 69 - 80 dan 1 orang (1,6 \%) memiliki daya ledak tungkai kaki 81 92.

\section{Hasil Balajar Praktek Tolak Peluru}

Pengukuran kemampuan tolak peluru dengan menggunakan Tes Tolak Peluru yang dilakukan terhadap sampel sebanyak 60 orang didapat skor terjauh(maximum) $949 \mathrm{~cm}(9,49$ meter $)$ minimum $420 \mathrm{~cm}$ (4,20 meter), rata-rata (mean) $736 \mathrm{~cm}$ ( 7,36 meter ), median $766 \mathrm{~cm}$ ( 7,66 meter ), simpangan baku (standar deviasi) $=117,62002$. untuk lebih jelasnya dapat dilihat pada tabel, berikut :

\begin{tabular}{cccc}
\multicolumn{4}{c}{ Tabel 5 : Distribusi Frekuensi kemampuan tolak peluru (Y). } \\
\hline No. & Interval Kelas (meter) & Frekuensi Absolute (fa) & Relatif (fr) \\
\hline 1 & $4,20-5,10$ & 5 & 9 \\
2 & $5,20-6,10$ & 6 & 11 \\
3 & $6,20-7,10$ & 10 & 17 \\
4 & $7,20-8,10$ & 20 & 33 \\
5 & $8,20-9,10$ & 16 & 27 \\
6 & $9,20-10,10$ & 3 & 3 \\
& Jumlah & 60 & $100 \%$
\end{tabular}

Mean $=736,35$

Median $=766$

Standar deviasi $=117,62$

Berdasarkan pada tabel distribusi frekuensi di atas dari 5 orang sampel, atau $(9 \%)$ memiliki kemampuan tolak peluru 4,20 - 5,13 meter. 6 orang atau (11\%) memiliki kemampuan tolak peluru $5,20-6,10$ meter, 10 orang atau (17\%) memiliki kemampuan tolak peluru 6,20-7,10 meter, 20 orang atau (33\%) memiliki kemampuan tolak peluru 7,20 - 8,10 meter, 16 orang atau (27\%) memiliki kemampuan tolak peluru 8,20 - 9,10 meter dan 3 orang atau (3\%) memiliki kemampuan tolak peluru $9,20-10,10$ meter.

\section{Analisis Data}

Sebelum melakukan pengujian hipotesis tentang hubungan variabel bebas dengan variabel terikat terlebih dahulu dilakukan uji persyaratan analisis data, yaitu uji normalitas data.

\section{Uji Normalitas Data}

Hasil analisis uji normalitas data masing-masing variabel di sajikan dalam tabel di bawah ini :

Tabel 6: Uji normalitas data daya ledak tungkai kaki (X) dengan Uji Shapiro Wilk.

\begin{tabular}{ccccccc} 
& \multicolumn{3}{c}{ Kolmogorov-Smirnov(a) } & \multicolumn{3}{c}{ Shapiro-Wilk } \\
& Statistic & df & Sig. & Statistic & Df & Sig. \\
\hline X1 &, 099 & 60 &, $200(*)$ &, 979 & 60 &, 408 \\
\hline
\end{tabular}

* This is a lower bound of the true significance.

a Lilliefors Significance Correction

Tabel menunjukkan bahwa hasil pengujian untuk daya ledak tungkai kaki (X) pada kolom Shapiro Wilk adalah 0,979 dengan probabilitas (sig.) 0,408. Dengan $\alpha>0,05$, maka dapat disimpulkan bahwa data berdistribusi normal. 
Tabel 7: Uji normalitas data kemampuan tolak peluru (Y) dengan Uji Shapiro Wilk.

\begin{tabular}{cccccrrr}
\hline & \multicolumn{4}{c}{ Kolmogorov-Smirnov(a) } & \multicolumn{4}{c}{ Shapiro-Wilk } \\
& Statistic & df & Sig. & Statistic & Df & \multicolumn{1}{c}{ Sig. } \\
\hline $\mathrm{Y}$ &, 116 & 60 &, 043 &, 946 & 60 &, 010 \\
\hline
\end{tabular}

a Lilliefors Significance Correction

Tabel menunjukkan bahwa hasil pengujian untuk kemampuan tolak peluru (Y) pada kolom Shapiro Wilk adalah 0,946 dengan probabilitas (sig.) 0,010. Dengan $\alpha>0,05$, maka dapat disimpulkan bahwa data berdistribusi normal. Berdasarkan uraian di atas semua variabel $\mathrm{X}$ dan $\mathrm{Y}$ datanya berdistribusi normal, karena masing-masing variabel probabilitasnya $>0,05$. Hal ini dapat dikatakan bahwa data masing-masing tersebar secara normal atau populasi dari data sampel diambil berdistribusi normal.

\section{Uji Reliabilitas dan Uji Validitas}

Tujuan utama dari pengujian reliabilitas adalah untuk mengetahui konsistensi atau keteraturan hasil pengukuran suatu instrumen apabila instrumen tersebut digunakan lagi sebagai alat ukur suatu objek atau responden. Hasil uji reliabilitas mencerminkan dapat dipercaya dan tidaknya suatu instrumen penelitian berdasarkan tingkat kemantapan dan ketepatan suatu alat ukur (Triton PB,2006). Sedangkan uji validitas atau kesahihan digunakan untuk mengetahui seberapa tepat alat ukur mampu melakukan fungsinya.

\section{a. Uji Reliabilitas}

Untuk mengetahui reliabilitas data pada penelitian ini dapat dilihat pada tabel di bawah ini :

Tabel 8. Hasil Uji Reliabilitas dengan SPSS. V.12

\begin{tabular}{cc}
\multicolumn{2}{c}{ Reliability Statistics } \\
\hline $\begin{array}{c}\text { Cronbach's } \\
\text { Alpha }\end{array}$ & $\begin{array}{c}\mathrm{N} \text { of } \\
\text { Items }\end{array}$ \\
\hline .289 & 2
\end{tabular}

Ini artinya nilai Alpha Cronbach's adalah 0.289 dengan jumlah variabel 2. Nilai $r_{\text {tabel }}$ untuk uji dua sisi pada taraf kepercayaan $95 \%$ atau signifikan $5 \%(p=0,05)$ dapat dicari berdasarkan jumlah sampel atau $\mathrm{N}$. oleh karena $\mathrm{N}=60$, maka derajat bebasnya adalah $\mathrm{N}-2=60-2=58$. pada nilai $\mathrm{r}_{\text {tabel }}$ satu sisi pada taraf $\mathrm{df}=20$ dan $\mathrm{p}=0,05$ adalah 0,250. Oleh karena nilai Alpha Cronbach's $=0.289$ ternyata lebih besar dari $\mathrm{r}_{\text {tabel }}=0,250$, maka data penelitian ini reliable.

b. Uji Validitas

Untuk mengetahui validitas data pada penelitian ini dapat dilihat pada tabel di bawah ini :

Tabel 9. Hasil Uji Validitas dengan SPSS. V.12 Item-Total Statistics

\begin{tabular}{lrrrr}
\hline & $\begin{array}{c}\text { Scale Mean if } \\
\text { Item Deleted }\end{array}$ & $\begin{array}{c}\text { Scale } \\
\text { Variance if } \\
\text { Item Deleted }\end{array}$ & $\begin{array}{c}\text { Corrected } \\
\text { Item-Total } \\
\text { Correlation }\end{array}$ & $\begin{array}{c}\text { Cronbach's } \\
\text { Alpha if Item } \\
\text { Deleted }\end{array}$ \\
\hline Daya ledak tungkai kaki & 736,3500 & 13834,469 &, 550 &, 576 \\
Kemampuan tolak peluru & 100.0000 & 346.926 &, 550 &, 608 \\
\hline
\end{tabular}

Dari tabel di atas semua variabel (Daya ledak tungkai kaki, Kemampuan tolak peluru) memiliki nilai Corrected Item-Total Correlation $>\mathrm{r}_{\text {tabel. }}$. Karena semua nilai Corrected Item-Total Correlation besar dari 0,250, maka dapat dikatakan semua instrumen penelitian valid untuk digunakan.

\section{Uji Hipotesis} berikutnya:

Untuk menguji hipotesis berdasarkan tabel matrik kolerasi yang disajikan pada halaman 
Sport Science: Jurnal Sain Olahraga dan Pendidikan Jasmani ISSN 114-562X (Cetak), ISSN XXXX-XXXX(Online)

http://sportscience.ppj.unp.ac.id/index.php/jss/index

Tabel 10: Rangkuman hasil analisis kolerasi Daya ledak tungkai kaki, Kemampuan tolak peluru.

\begin{tabular}{|c|c|c|c|}
\hline & & $\begin{array}{c}\text { Daya ledak } \\
\text { tungkai kaki }\end{array}$ & $\begin{array}{l}\text { Kemampuan } \\
\text { tolak peluru }\end{array}$ \\
\hline $\begin{array}{l}\text { Daya ledak tungkai } \\
\text { kaki }\end{array}$ & $\begin{array}{l}\text { Pearson } \\
\text { Correlation } \\
\text { Sig. (2-tailed) } \\
\text { N }\end{array}$ & 60 & $\begin{array}{r}.550(* *) \\
.000 \\
03\end{array}$ \\
\hline $\begin{array}{l}\text { Kemampuan tolak } \\
\text { peluru }\end{array}$ & $\begin{array}{l}\text { Pearson } \\
\text { Correlation } \\
\text { Sig. (2-tailed) } \\
\text { N }\end{array}$ & $\begin{array}{r}.550(* *) \\
.000 \\
60 \\
\end{array}$ & $\begin{array}{r}1 \\
60\end{array}$ \\
\hline
\end{tabular}

** Correlation is significant at the 0.01 level (2-tailed).

Terdapat hubungan yang berarti antara Daya ledak tungkai kaki dan Kemampuan tolak peluru. Berdasarkan analisis yang dilakukan, maka didapat skor rata-rata Daya ledak tungkai kaki sebesar 54,2167 dengan simpangan baku 12,62241. Untuk skor rata-rata Kemampuan tolak peluru didapat 736,3500 dan simpangan baku 117,62002. Dari tabel di atas diperoleh analisis kolerasi antara daya ledak tungkai kaki dan kemampuan tolak peluru sebagai berikut :

$\mathrm{r}_{\mathrm{o}}=0,550 \quad \mathrm{r}_{\mathrm{tab}}(\alpha=0,05)=0,250$

sig $=0,000$

ternyata $r_{o}>r_{\text {tab }}$ akibatnya Ho ditolak (Ha diterima)

Tabel 11: Analisis kolerasi antara Daya ledak tungkai kaki dan Kemampuan tolak peluru.

\begin{tabular}{ccccc}
\hline $\mathrm{dk}(\mathrm{N}-2)$ & $\mathrm{r}_{\text {hitung }}$ & $\mathrm{r}^{2}$ hitung & $\begin{array}{c}\mathrm{r}_{\text {tabel }} \\
\alpha=0,05\end{array}$ & kesimpulan \\
\hline 58 & 0,550 & 0,302 & 0,250 & Signifikan
\end{tabular}

Ket : $\mathrm{dk}=$ derajat kebebasan

Hasil analisis kolerasi menyatakan terdapat hubungan yang berarti antara Daya ledak tungkai kaki dan Kemampuan tolak peluru pada taraf signifikan $\alpha=0,05$, dalam hal ini hipotesis diterima kontribusinya sebesar $30,2 \%$.

\section{Pembahasan}

Perhitungan kolerasi antara daya ledak tungkai kaki (X) dengan kemampuan tolak peluru (Y) menggunakan rumus kolerasi product moment. Kriteria pengujian jika $r_{\text {hitung }}>r_{\text {tabel}}$, maka terdapat hubungan yang signifikan dan sebaliknya (sudjana 1992:369). Dari hasil perhitungan kolerasi antara daya ledak tungkai kaki dengan kemampuan tolak peluru diperoleh $r_{\text {hitung }} 0,550$ sedangkan $r_{\text {tabel }}$ pada taraf signifikan $\alpha=0,05$ yaitu 0,250 . Berarti dalam hal ini tingkat hubungan daya ledak tungkai kaki dengan kemampuan tolak peluru sebesar 30,2 \%, dengan demikian semakin baik daya ledak tungkai kaki seseorang maka semakin baik pula kemampuan tolak pelurunya.

Dari hasil analisis di atas dapat diambil kesimpulan bahwa terdapat hubungan yang signifikan antara daya ledak tungkai kaki dengan kemampuan tolak peluru. Daya ledak tungkai kaki yang dimiliki sampel juga akan lebih baik dengan adanya latihan sehingga dengan proses latihan diharapkan daya ledak tungkai kakinya semakin meningkat dan memberi pengaruh yang besar terhadap kemampuan tolak peluru.

Perhitungan kolerasi antara daya ledak tungkai kaki (X) dengan kemampuan tolak peluru (Y) menggunakan rumus kolerasi product moment. Kriteria pengujian jika $\mathrm{r}_{\text {hitung }}>\mathrm{r}_{\text {tabel }}$, maka terdapat hubungan yang signifikan dan sebaliknya (sudjana 1992 : 369). Dari perhitungan korelasi antara daya ledak tungkai kaki dengan kemampuan tolak peluru diperoleh $r_{\text {hitung }} 0,550$ sedangkan $r_{\text {tabel }}$ pada taraf signifikan $\alpha=0,05$ yaitu 0,250 . Berarti dalam hal ini tingkat hubungan daya ledak tungkai kaki dengan 
kemampuan tolak peluru sebesar 30,2\%, maksudnya semakin bagus daya ledak tungkai kaki seseorang maka semakin baik pula kemampuan tolak peluru.

Dari hasil analisis diatas dapat diambil kesimpulan bahwa terdapat hubungan yang signifikan antara daya ledak tungkai kaki dengan kemampuan tolak peluru. Daya ledak tungkai kaki yang dimiliki sampel juga akan lebih baik dengan adanya latihan sehingga dengan proses latihan diharapkan daya ledak tungkai kaki semakin meningkat dan memberikan sumbangan besar terhadap kemampuan tolak peluru.

Dilihat dari analisis data yang dilakukan maka daya ledak tungkai kaki dengan kemampuan tolak peluru juga terdapat hubungan yang signifikan, karena dengan adanya latihan yang dilakukan sampel sehingga daya ledak tungkai kaki semakin kuat. kemampuan tolak peluru tergantung pada daya ledak tungkai kaki, semakin bagus daya ledak tungkai kaki maka semakin bagus kemampuan tolak peluru.

\section{KESIMPULAN}

Berdasarkan hasil penelitian yang telah diuraikan pada bab terdahulu dapat dikemukakan kesimpulan bahwa hasil yang peroleh dari daya ledak tungkai kaki mempunyai hubungan yang signifikan dengan Kemampuan tolak peluru, ini ditandai dengan hasil yang diperoleh yaitu $\mathrm{r}_{\text {hitung }}$ $0,550>\mathrm{r}_{\text {tabel }} 0,250$ dan berdasarkan analisis data yang diperoleh dapat disimpulkan bahwa semakin bagus daya ledak tungkai kaki maka semakin baik pula hasil belajar praktek tolak peluru. Yang dibuktikan dengan hasil yang peroleh yaitu adanya kontribusi yang berarti antara daya ledak tungkai kaki terhadap kemampuan tolak peluru sebesar $30.2 \%$.

Selanjutnya berdasarkan pada kesimpulan tersebut maka peneliti dapat memberikan saransaran yang dapat membantu mengatasi masalah yang ditemui dalam pelaksanaan Kemampuan tolak peluru, seperti kepada para mahasiswa disarankan untuk menerapkan dan memperhatikan tentang daya ledak tungkai kaki dalam menjalankan program latihan, di samping kondisi - kondisi lain yang ikut menunjang keberhasilan Kemampuan tolak peluru.

Untuk mendapatkan hasil yang optimal khususnya daya ledak tungkai kaki, peneliti menyarankan pada para pelatih untuk memberikan latihan-latihan khusus yang dapat mengembangkan kemampuan daya ledak tungkai kaki. Kepada atlit tolak peluru agar memperhatikan kondisi daya ledak tungkai kaki untuk dapat melakukan latihan kondisi fisik yang lain di dalam menunjang daya ledak tungkai kaki dan bagi para peneliti disarankan untuk dapat mengkaji kondisi - kondisi lain yang berhubungan dengan Kemampuan tolak peluru.

\section{DAFTAR RUJUKAN}

AIP. Syarifuddin (1992). Ateltik. Depdikbud. Dikti

Ambayar (1990) Hubungan Hasil Belajar Mata Kuliah Teori Belajar dan Mengajar Khusus Terhadap Sikap Mengenai Jabatan Guru pada Mahasiswa FPTK. Padang. IKIP Padang.

Amran (1993). Perbedaan Antara Hasil Belajar Mata Kuliah Praktek Mahasiswa PMDK Dengan Mahasiswa PGSD pada Program DII PGSD Penjas IKIP Padang. Padang. IKIP Padang.

Argantos (1989). Pengaruh Metode Mengajar dan Potensi Alat Gerak Tubuh Terhadap Hasil Belajar Renang Mahasiswa PGSD Penjas (Laporan Penelitian) IKIP. Padang.

Arikunto, Suharsimi (2006), Prosedur Penelitian Suatu Pendekatan Praktik. Jakarta : Rineka Cipta.

Arsil. (1999). Pembinaan Kondisi Fisik. Padang : FIK UNP 
Sport Science: Jurnal Sain Olahraga dan Pendidikan Jasmani ISSN 114-562X (Cetak), ISSN XXXX-XXXX(Online)

http://sportscience.ppj.unp.ac.id/index.php/jss/index

Harsono (1998). Coaching dan Aspek-aspek Psikologis dalam Coaching.

Lutan, Rusli (1978). Belajar Keterampilan Motorik Pengantar Teori dan Praktek: Depdikbud Dirjen Dikti.

Mutohir, (2004). Pengadaan Taman Olahraga Masyarakat, Jakarta.

PASI. (1993). Pengenalan Kepada Teori Pelatihan. Jakarta.

PASI. (1993) Pedoman Dasar Melatih Atletik. Jakarta : Program Pendidikan Dan Sertifikasi Pelatih Atletik Pasi.

Sajoto. M (1988). Pembinaan Kondisi Fisik Dalam Olahraga. Jakarta : Depdikbud.

Slameto (1995). Belajar dan Faktor-faktor yang Mempengaruhi. Jakarta. Rineka Cipta.

Sajoto. M (1988). Pembinaan Kondisi Fisik Dalam Olahraga. Jakarta : Depdikbud.

Sudjana. (1994). Metode Statistika. Tarsito. Bandung.

Suharno. (1993). Metodologi Pelatihan. Jakarta : KONI Pusat

Syafrudin. (1992). Pengantar Ilmu Melatih. Padang : FPOK IKIP

UNP (2003). Panduan Akademik. Padang. 